\title{
Retinal dendritic cell recruitment, but not function, was inhibited in MyD88 and TRIF deficient mice
}

\author{
Neal D Heuss ${ }^{1}$, Mark J Pierson ${ }^{1}$, Kim Ramil C Montaniel ${ }^{1}$, Scott W McPherson ${ }^{1}$, Ute Lehmann ${ }^{1}$, Stacy A Hussong ${ }^{1}$, \\ Deborah A Ferrington', Walter C Low ${ }^{2}$ and Dale S Gregerson ${ }^{1 *}$
}

\begin{abstract}
Background: Immune system cells are known to affect loss of neurons due to injury or disease. Recruitment of immune cells following retinal/CNS injury has been shown to affect the health and survival of neurons in several models. We detected close, physical contact between dendritic cells and retinal ganglion cells following an optic nerve crush, and sought to understand the underlying mechanisms.

Methods: CD11c-DTR/GFP mice producing a chimeric protein of diphtheria toxin receptor (DTR) and GFP from a transgenic CD11c promoter were used in conjunction with mice deficient in MyD88 and/or TRIF. Retinal ganglion cell injury was induced by an optic nerve crush, and the resulting interactions of the GFPhi cells and retinal ganglion cells were examined.

Results: Recruitment of GFPhi dendritic cells to the retina was significantly compromised in MyD88 and TRIF knockout mice. GFPhi dendritic cells played a significant role in clearing fluorescent-labeled retinal ganglion cells post-injury in the CD11c-DTR/GFP mice. In the TRIF and MyD88 deficient mice, the resting level of GFPhi dendritic cells was lower, and their influx was reduced following the optic nerve crush injury. The reduction in GFPhi dendritic cell numbers led to their replacement in the uptake of fluorescent-labeled debris by GFPlo microglia/macrophages. Depletion of GFPhi dendritic cells by treatment with diphtheria toxin also led to their displacement by GFPlo microglia/ macrophages, which then assumed close contact with the injured neurons.

Conclusions: The contribution of recruited cells to the injury response was substantial, and regulated by MyD88 and TRIF. However, the presence of these adaptor proteins was not required for interaction with neurons, or the phagocytosis of debris. The data suggested a two-niche model in which resident microglia were maintained at a constant level post-optic nerve crush, while the injury-stimulated recruitment of dendritic cells and macrophages led to their transient appearance in numbers equivalent to or greater than the resident microglia.
\end{abstract}

Keywords: Dendritic cells, Injury, Microglia, Retinal ganglion cells, NFkB

\section{Background}

Neurodegenerative processes adversely affect vision in a significant portion of the human population, and are associated with glaucoma, age-related macular degeneration (AMD), diabetic retinopathy, ischemia, retinopathy of prematurity and traumatic injuries [1-4]. Irrespective of the cause of the degenerative process, it is evident that the immune system can be protective or pathogenic in neurodegeneration [5]. Studies show that microglia

\footnotetext{
* Correspondence: grege001@umn.edu

'Department of Ophthalmology \& Visual Neurosciences, University of Minnesota, Lions Research Bldg. Rm 314, 2001 6th St SE, Minneapolis, MN 55455, USA

Full list of author information is available at the end of the article
}

(MG) are not simply the scavengers of the nervous system; instead, they appear to play complicated, even contradictory, roles [6,7]. MG have been associated with clean-up of dead/dying neurons with minimal inflammation $[8,9]$, restoration of health to damaged peripheral nervous system (PNS) neurons [10], and promotion of inflammation through secretion of proinflammatory molecules [11,12]. They also appear to kill neurons through effector mechanisms that include production of reactive oxygen species which disrupt axonal transport [13], and cytotoxic cytokines including TNF. FasL expression by MG may contribute to the death of $\mathrm{Fas}^{+}$ neurons $[14,15]$. 
Regardless of the injury, MG are rapid responders. Within minutes of a focal injury to brain or retina, neighboring MG extended processes to the site [16-18]. At later time points post-injury, other cells participate. The optic nerve crush (ONC) has been used as a model for neural injury, giving a discreet injury to a limited number of neurons, retinal ganglion cells, that progresses on a well-studied, consistent course $[19,20]$. By two to three days post-ONC, we found evidence that dendritic cells (DC) were recruited to the retina, increasingly associated with the ganglion cell layer (RGC) and the nerve fiber layer (NFL) of the retina, and increased in number for approximately ten days, equaling the MG in total number per retina [21]. The number of DC remained elevated for more than two months, gradually declining in number. Many DC were closely associated with the axons of RGC post-ONC [21]. DC dominated this close interaction for at least three weeks post-injury, raising the question of whether their response was protective, harmful, or unrelated to survival of RGC.

The well-known function of DC as antigen presenting cells may be important, consistent with reports that suggest that adaptive immunity mediated by $\mathrm{T}$ cells may be neuroprotective [22-25]. However, very few lymphocytes were found after this sterile injury, suggesting that the activity of these DC may not be limited to antigen presentation. We present evidence that DC are active participants in the injury response. Analysis of DC from MyD88 and TRIF single and double knockout mice showed that DC in the knockout mice were much less efficiently recruited to the retina post-injury, but the smaller number that was present remained fully able to take up $\mathrm{DiI}^{+}$debris via phagocytosis of DiI-labeled RGC and axon debris after an ONC. MG compensated for the reduced number of DC in MyD88 and/or TRIF deficient mice by increasing their uptake of $\mathrm{DiI}^{+}$debris.

\section{Materials and methods \\ Animals}

CD11c-DTR/GFP mice (CDG) mice on the B6 background (B6.FVB-Tg(Itgax-DTR/EGFP)57Lan/J), express a chimeric protein comprised of GFP and the diphtheria toxin receptor (DTR) under control of the CD11c promoter [26]. Wild type (wt) C57BL/6J (B6) mice were obtained from Jackson Laboratory (Bar Harbor, ME, USA). MyD88/TRIF double knockout mice (MTdko) on the B6 background were bred from pairs obtained from Dr. Stephen Jameson, University of Minnesota. The double knockout mice were backcrossed to $\mathrm{B} 6$ mice to generate the single knockout mice, MyD88-deficient (Mko) mice and TRIF-deficient (Tko) mice. The single and double knockout mice were backcrossed to CDG mice to allow visualization of the GFP reporter for CD11c. All mice were CD45.2. Transgenic mice were bred in house. All mice were $r d 8$ negative. Mice were handled in accordance with the Association for Research in Vision and Ophthalmology Statement for the Use of Animals in Ophthalmic and Vision Research and University of Minnesota Institutional Animal Care and Use Committee guidelines.

\section{Optic nerve crush}

The optic nerve crush (ONC) was performed as described [21,27], except for use of \#2197E DSAEK forceps (Ambler Surgical Corp., Exton, PA, USA) for the crush procedure. Briefly, the optic nerve was clamped for three seconds at a point 1 to $2 \mathrm{~mm}$ from the posterior pole of the globe.

\section{RGC labeling}

Injection of fluorescent dye, either Fluorogold (FG) or di-alkyl-indocarbocyanine (DiI), into the superior colliculus was done to retrogradely label the RGC. Manipulations were done in a stereotactic device. A midline incision was made in the scalp to expose the skull. A unilateral $1 \mathrm{~mm}$ hole was drilled at $-3.5 \mathrm{~mm}$ from bregma and $+1.2 \mathrm{~mm}$ from midline. A $10-\mu \mathrm{l}$ syringe and non-coring needle attached to a micromanipulator was inserted to a depth of $-2.5 \mathrm{~mm}$ from the surface of the brain. Four percent dye in $1.5 \mu \mathrm{l}$ of saline was injected over the course of 2 minutes. After slow removal of the syringe, the scalp was sutured with 4-0 silk. FG was used to count surviving RGC and was administered after the ONC four days before retina harvest. The FG diffuses rapidly to the opposite hemisphere of the brain, so that the RGC of both retinas become equivalently stained even if the dye was injected unilaterally in the brain. DiI was used to label the RGC with red fluorescence for experiments to detect labeled RGC debris in the mononuclear cells of the retina by flow cytometry and fluorescence microscopy. DiI was administered seven to ten days before the ONC.

\section{Flow cytometry of retinal cells}

Mice were euthanized, perfused, and the retinas removed as described [21]. Retinas were dissociated in $0.5 \mu \mathrm{g} / \mathrm{ml}$ Liberase/Blendzyme3 (Roche, Indianapolis, IN, USA) and $0.01 \%$ DNase in Dulbecco's phosphatebuffered saline (DPBS), stained with indicated antibodies, and analyzed as described [21,28,29]. Analyses were based on the examination of all immune cells collected from one or more retinas, as specified.

\section{Immunostaining of retinal flatmounts}

Retinal flatmounts were prepared, stained, and analyzed as described [21]. Primary antibodies included: rat antiCD11b to stain myeloid cells (clone M1/70, BD Biosciences, San Jose, CA, USA) and anti- $\beta 3$-tubulin to stain 
RGC and their axons (clone TU-20). Secondary antibodies (Invitrogen, Life Technologies, Grand Island, NY, USA) included: Alexa Fluor 594 donkey anti-rat IgG for anti-CD11b; and Alexa Fluor 405 rabbit anti-mouse IgG for anti- $\beta 3$ tubulin. Cell nuclei were stained with 4',6diamidino-2-phenylindole (DAPI, Vector Laboratories, Burlingame, CA, USA).

\section{TUNEL-stained retinal sections}

Eyes were enucleated and immediately snap-frozen in Tragacanth (Sigma, St. Louis, MO, USA). Retinas were sectioned $(12 \mu \mathrm{m})$ through the optic nerve. Detection of apoptotic nuclei was accomplished by terminal deoxynucleotidyl transferase-mediated dUTP nick-end labeling (TUNEL) using the In Situ Cell Death Detection Kit, Fluorescein (Roche, Indianapolis, IN, USA). Slides were cover slipped with VECTASHIELD Mounting Medium containing DAPI (Vector Laboratories, Burlingame, CA, USA) to visualize the nuclei.

\section{Retinal morphology measurements}

The density of nuclei in the ganglion cell layer (GCL) was measured on DAPI-stained retinal sections. For each retinal section, three images were taken on either side of the optic nerve at $500 \mu \mathrm{m}$ intervals. The length of the GCL was measured using BIOQUANT NOVA PRIME 6.90.10 (BIOQUANT Image Analysis, Nashville, TN, USA). The number of DAPI-stained nuclei in the GCL was counted from these images and normalized to the length of the retinal section to calculate the nuclei density (nuclei/ $\mu \mathrm{m})$. The same retinal sections were also stained with TUNEL. The TUNEL ${ }^{+}$nuclei in these same sections were counted and cross-referenced with the DAPI stained nuclei to ensure presence of a nucleus.

\section{Statistics}

Data, whether expressed numerically or graphically as a mean, included the standard deviation; standard error was not used. Data analyses for significance were done with the InStat3 package from GraphPad Software (San Diego, CA, USA). Comparisons of three or more data sets were done with one way analysis of variance (ANOVA) using the Dunnett multiple comparisons test with a designated control set. Comparisons of two data sets were done with a two-tailed, unpaired $t$-test.

\section{Results}

\section{Optic nerve crush injury}

The ONC procedure yielded a significant, reproducible sterile injury to the RGC (Figure 1), providing the opportunity to study factors that may affect recruitment of mononuclear cells and their interactions with the injured RGC. Survival of RGC from wt B6 mice and CDG mice was similar (Figure 1). The autocount procedure and results are described in the Additional file 1: Figure S1. Extrapolating our counts/field to the entire normal C57BL/ 6J retina yielded a total of $46,324 \pm 1,968 \mathrm{RGC}$, which compares well with values from other reports obtained by counting axons $(44,860$ [30] and 47,113 [31]) or retrograde labeled RGC $(49,823$ [32]).

\section{Identification of retinal DC and MG/macrophages}

We previously showed that the $\mathrm{CD} 11 \mathrm{~b}^{+} \mathrm{GFP}^{\text {hi }}$ cells in quiescent CDG retina were morphologically similar to MG [21]. Flow cytometry showed that the CD11b ${ }^{+} \mathrm{GFP}^{\text {lo }}$ and $\mathrm{CD} 11 \mathrm{~b}^{+} \mathrm{GFP}^{\mathrm{hi}} \mathrm{DC}$ in the $\mathrm{CD} 45^{\text {med }}$ region commonly associated with MG were indistinguishable by several parameters, including expression of $\mathrm{F} 4 / 80$, whether from quiescent or post-ONC retinas (Figure $2 \mathrm{~A}$ ). The CD $45^{\text {hi }}$ region also contains a small number of $\mathrm{CD}_{11} \mathrm{~b}^{+}$cells,

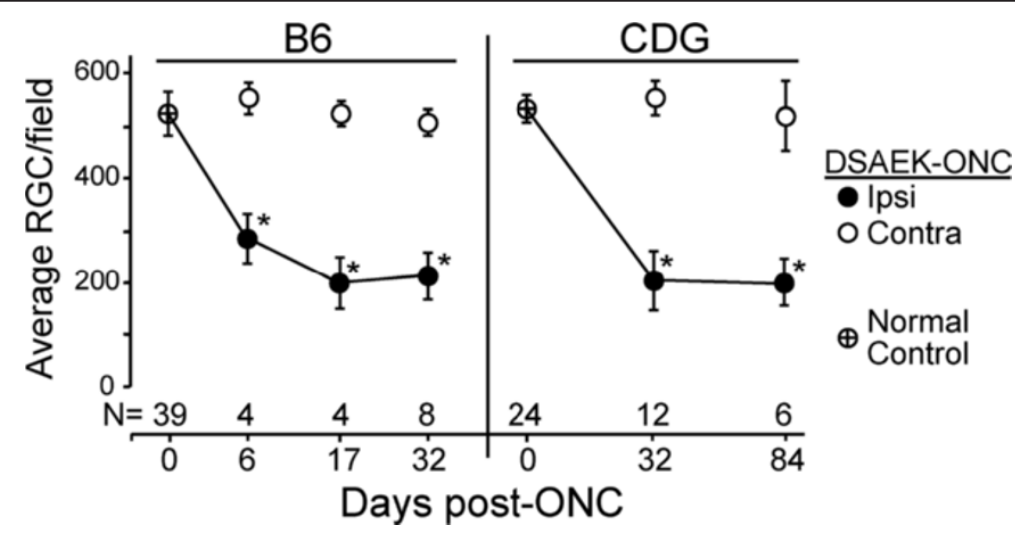

Figure 1 CDG and B6 retinal ganglion cells (RGC) survive similarly after an optic nerve crush (ONC). RGC survive in greater numbers using DSAEK forceps for the ONC. *All post-ONC counts of RGC differed from normal controls, as well as the contralateral RGC, $P<0.05$. Normal control RGC counts represent the RGC counts of both retinas after unilateral injection into the superior colliculus. Ipsilateral - manipulated side; contralateral opposite, unmanipulated side. Counts are average RGC numbers/retinal field where each retina count is the average of eight fields/retina, \pm SD. $\mathrm{N}=$ number of mice. For example, an $\mathrm{N}$ of 4 represents 32 fields. Field size $=0.190 \mathrm{~mm}^{2}$. 
A CD45 ${ }^{\text {med }}$ naive $\mathrm{B} 6$
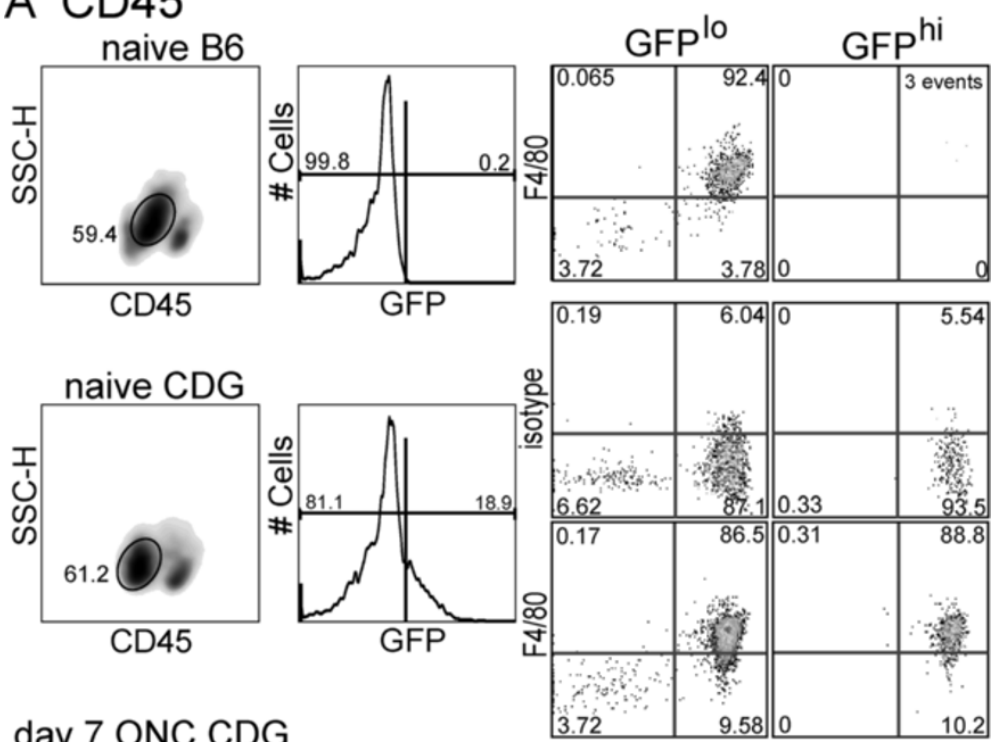

day 7 ONC CDG
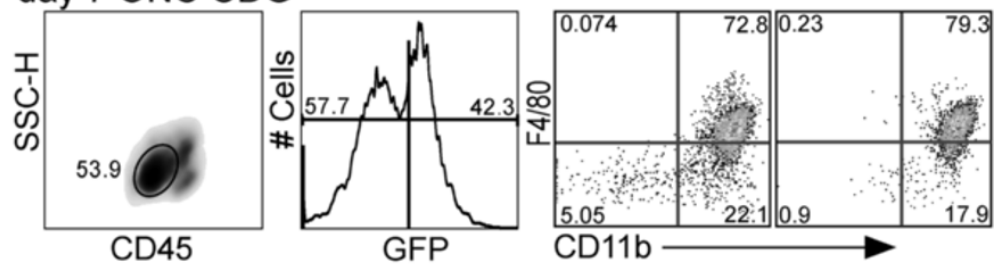

\section{B CD45 hi}
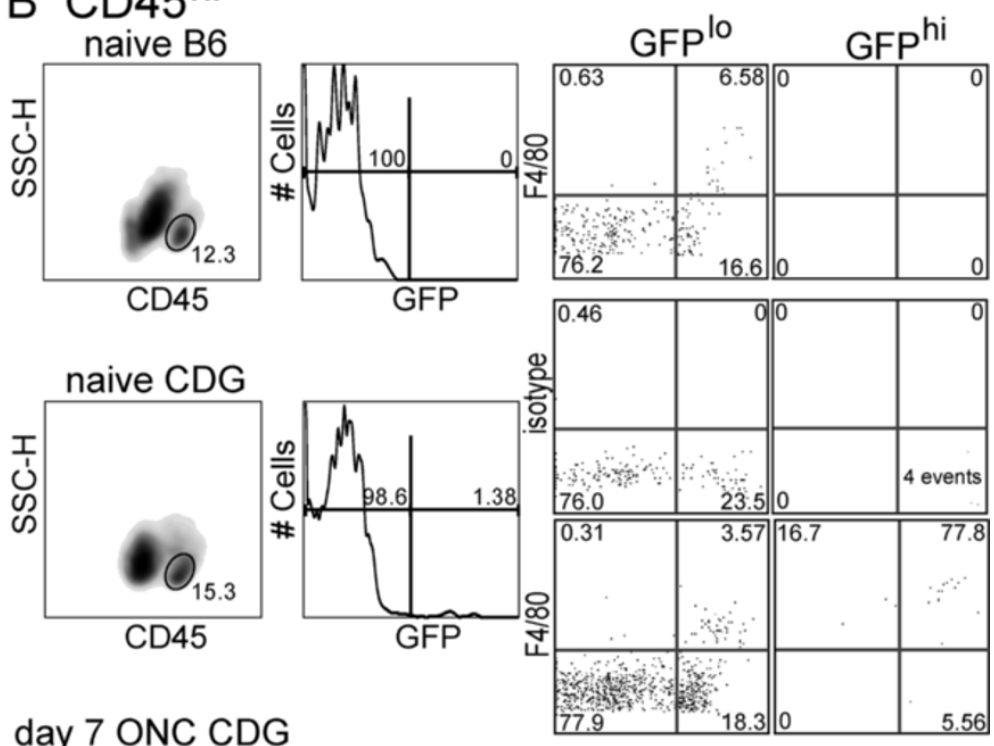

day 7 ONC CDG
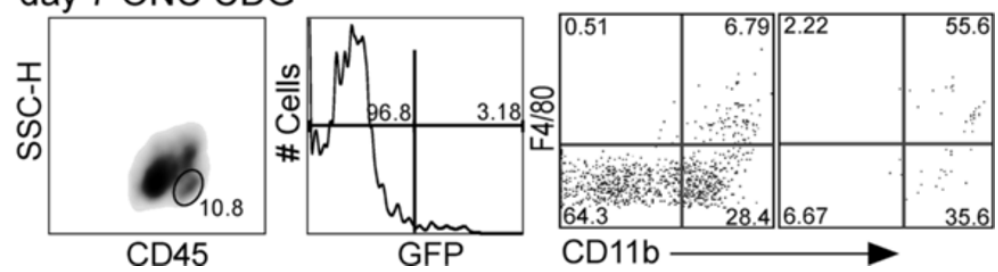

Figure 2 (See legend on next page.) 
most are $\mathrm{F} / 80^{+}$(Figure 2B). The influx of $\mathrm{GFP}^{\mathrm{hi}}$ cells post-ONC was easily detected by sequentially gating on $\mathrm{CD} 45^{+}$cells, and then confirming that the GFP ${ }^{\text {hi }}$ cells expressed CD11b. At 7 days post-crush, the GFP ${ }^{\text {hi }}$ cells accounted for approximately $40 \%$ of the total $C D 45^{+} 11 \mathrm{~b}^{+}$ cells. The $\mathrm{CD}_{11 \mathrm{~b}^{+}} \mathrm{GFP}^{\mathrm{hi}}$ cells do not express detectable levels of Ly6G (clone 1A8) or Ly6C/G (Gr-1, clone RB68C5 (data not shown)), showing that neutrophils did not contribute to the counts. These properties allowed identifying these cells in four groups (Table 1) for the studies that follow.

\section{Retinal DC associate with RGC axons and soma after an ONC}

In quiescent retina, a small number of ramified $\mathrm{GFP}^{\text {hi }}$ DC were distributed in the inner plexiform layer (IPL) immediately below the soma of the RGC (Figure 3A). This morphology was unchanged at day 1 post-ONC (Figure 3A). DC in close association with injured RGC were first detected three days post-ONC, when a careful search of three retinas found a few GFP ${ }^{\text {hi }}$ DC closely associated with RGC nerve fibers (Figure 3A). Dendrites (small blue arrows) show GFP $^{\text {hi }}$ DC in the IPL at day 1 and day 3a. Large blue arrows show axons bundled into nerve fibers (day 3b). Somata (white/blue arrows) are shown in days $3 \mathrm{~b}$ and $7 \mathrm{a}$. By five days post-ONC, numerous close associations between the GFP ${ }^{\text {hi }}$ DC and nerve fibers were found (Figure 3A). Counts of representative 20X fields from three retinas harvested at day 5 post-ONC showed that $16 \%$ of the total $\mathrm{GFP}^{\text {hi }}$ DC in retina were closely associated with nerve fibers or soma. Close association of the GFP ${ }^{\text {hi }}$ DC with the NFL peaked at 7 to 11 days (Figure 3A). We previously showed that $\mathrm{GFP}^{\text {hi }}$ DC dominated the interaction of $\mathrm{CD} 11 \mathrm{~b}^{+}$cell populations with the NFL at seven days post-ONC [21]. By 11 days post-ONC, the density of $\beta 3$-tubulin ${ }^{+}$fibers

\begin{tabular}{|c|c|c|c|c|}
\hline CDG retinal cells & GFP $^{a}$ & $\mathrm{CD}^{2} 5^{\mathrm{a}}$ & $C D 11 b^{a}$ & $\mathrm{~F} 4 / 80^{\mathrm{a}}$ \\
\hline GFPhi DC (CD45 $\left.^{\text {med }}\right)$ & hi & med & hi & + \\
\hline GFPhi DC $\left(C D 45^{\text {hi }}\right)$ & hi & hi & hi & + \\
\hline $\begin{array}{l}\text { MG/monocyte/macrophage } \\
\text { (CD45 }\end{array}$ & $10^{b}$ & med & hi & + \\
\hline monocyte/macrophage (CD45 & lo & hi & hi & + \\
\hline
\end{tabular}

${ }^{\mathrm{a}}$ Flow cytometry.

${ }^{\mathrm{b}}$ Resistant to DTx depletion in CDG mice. in the NFL was reduced, but GFP ${ }^{\text {hi }}$ DC were still found in close contact with remaining fibers (Figure 3A). At five or more days post-ONC, DC were found in contact with the RGC soma, and these appeared to be engulfing the RGC (Figure 3B). The close association of the DC with the RGC and their axons raised questions about the molecular basis for these interactions that may affect RGC survival following an ONC.

\section{Roles of DC versus MG/macrophages in clearance of damaged RGC}

Candidate phagocytic cells in the retina that may clear damaged RGC are $\mathrm{CD} 45^{+} \mathrm{CD} 11 \mathrm{~b}^{+} \mathrm{Ly}_{6 \mathrm{G}^{-}}$mononuclear cells. To detect the relative contributions of MG, recruited macrophages, and recruited GFP ${ }^{\text {hi }} \mathrm{DC}$ to the clearance of injured RGC post-ONC, the RGC were prelabeled with DiI to detect $\mathrm{CD} 45^{+} \mathrm{CD} 11 \mathrm{~b}^{+}$cells that had phagocytosed DiI-labeled RGC. The $\mathrm{CD}_{11} \mathrm{~b}^{+}$phagocytic cells in the retina are found in two populations based on CD45 staining intensity, CD $45^{\mathrm{hi}}$ and CD $45^{\mathrm{med}}$ (Figure 4A, Table 1). The CD45 hi population of CDG retina contains $\mathrm{CD}_{11} \mathrm{~b}^{+}$cells that include $\mathrm{GFP}^{\mathrm{hi}} \mathrm{DC}, \mathrm{GFP}^{\mathrm{lo}}$ monocytes, macrophages, and polymorphonuclear granulocytes (PMN). The PMN were excluded by staining with clone $1 \mathrm{~A} 8$, which identifies $\mathrm{Ly}_{6 \mathrm{G}}^{+}$PMN. Although PMN are recruited onto the retinal surface at early time points postONC, a PMN in contact with the NFL or RGC was not observed (data not shown), and they were routinely excluded from further analysis. The $\mathrm{CD} 45^{\mathrm{med}}$ population post-ONC includes $\mathrm{MG}$, recruited macrophages and GFP $^{\text {hi }}$ DC (Figure 4A, Table 1).

As shown by others, and in Figure 4B, RGC were welllabeled seven days after injection of DiI into the superior colliculus [33]. After seven days DiI labeling, mice were given an ONC. Seven days post-ONC, $\mathrm{DiI}^{+} \mathrm{RGC}$ were being engulfed by $\mathrm{GFP}^{\mathrm{hi}} \mathrm{DC}$, as shown in a series of $1-\mu \mathrm{m}$ optical sections from confocal microscopy (Figure 4B). Slices 2, 4, 6 and 8 show the association of the DC with individual RGC somata at $2-\mu \mathrm{m}$ increments. Further verification that $\mathrm{CD}_{11} \mathrm{~b}^{+}$cells would take up DiI-labeled cellular debris after an ONC was found by flow cytometric analysis of retinas after seven days DiI labeling followed by an ONC. The retinas were harvested at day 6 postONC. DiI labeling was found in both the GFP ${ }^{\text {hi }}$ DC and GFP $^{\text {lo }} \mathrm{MG} /$ macrophages from the $\mathrm{CD} 45^{\text {med }}$ population (Figure 4C). This gating strategy was used for further analysis of $\mathrm{DiI}^{+} \mathrm{DC}$ and macrophages. 

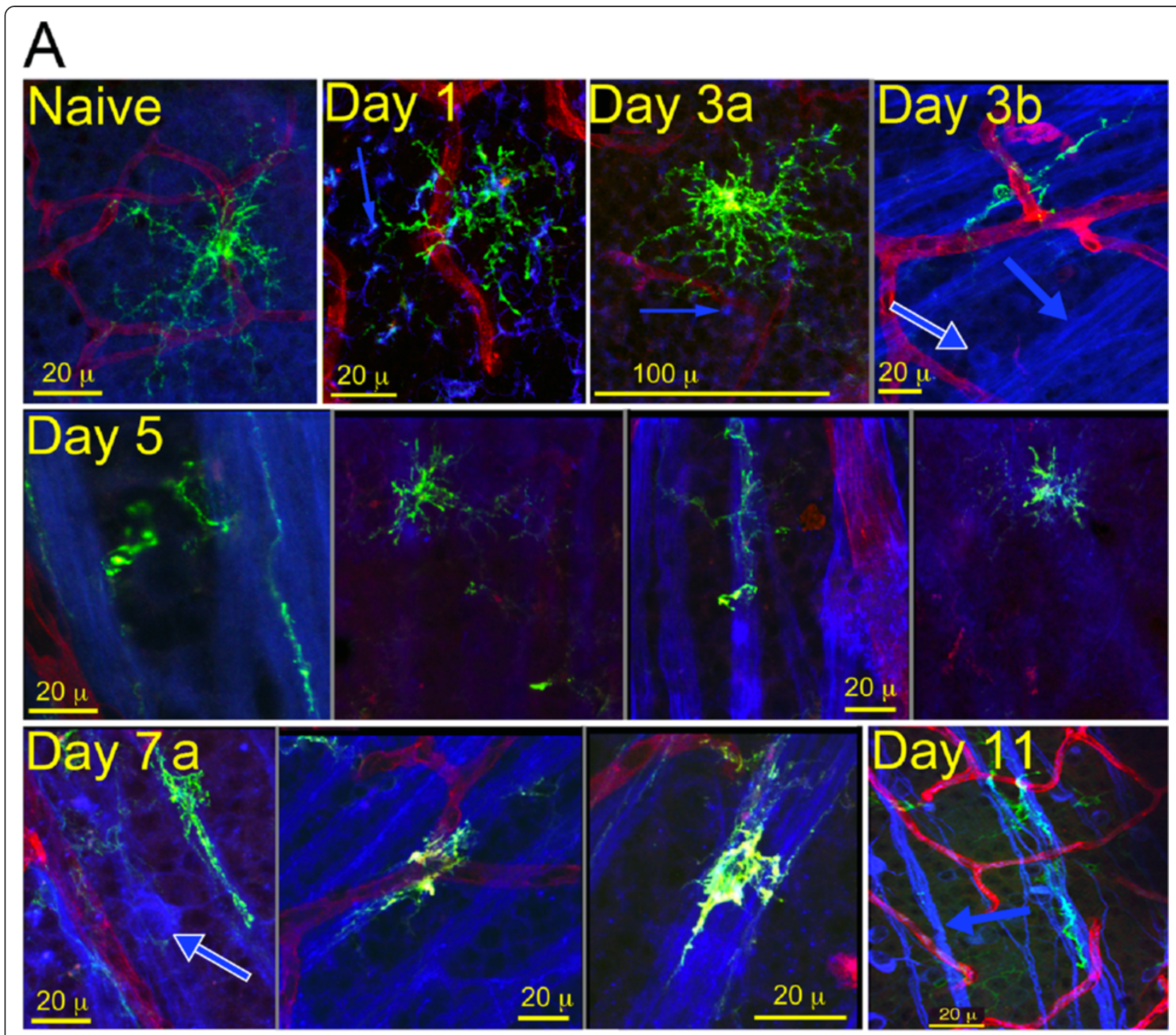

\section{B}
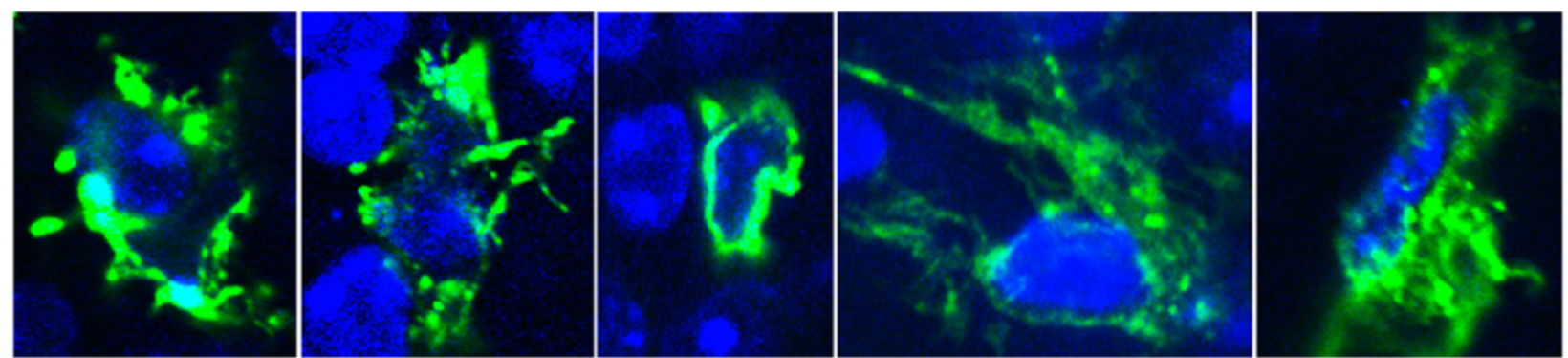

Figure 3 Recruitment, redistribution and interaction of retinal GFP ${ }^{\text {hi }}$ DC with retinal ganglion cells (RGC) and their axons following an optic nerve crush (ONC) injury. (A), GFPhi DC in naive retina, and at 1, 3, 5, 7, and 11 days post-ONC. GFP ${ }^{\text {hi }}$ DC, green; isolectin B4-stained blood vessels, red; anti- $\beta 3$ tubulin stained RGC somata (blue/white arrows), nerve fibers (large blue arrows), and dendrites (small blue arrows). (B), GFPhi DC surround and engulf RGC somata ten days post-ONC. DAPI, blue; GFPhi DC, green. 

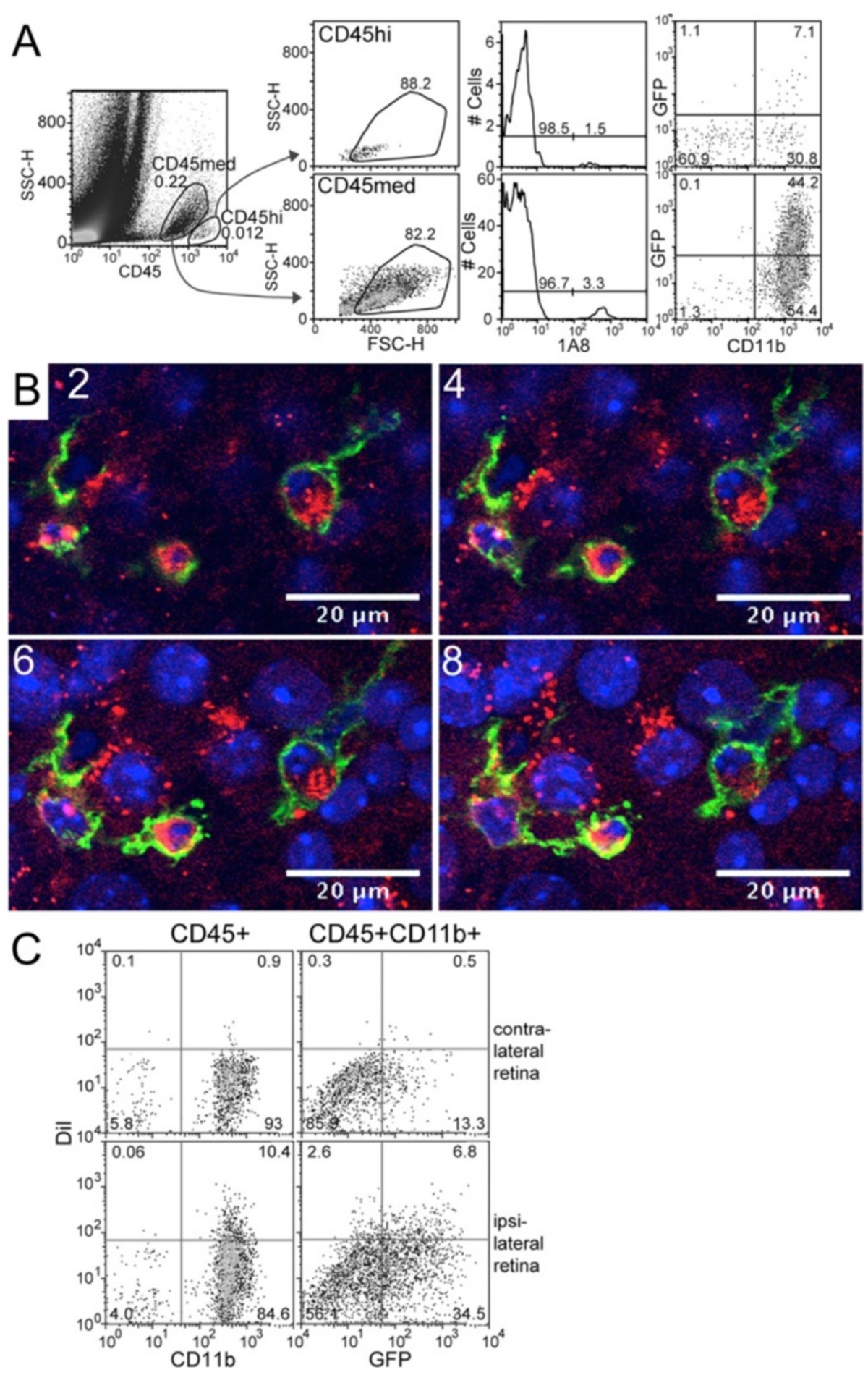

Figure 4 Detection of retinal ganglion cell (RGC) phagocytosis by GFPhi and GFPlo CD11 b cells in CDG retina post-ONC. (A) Depiction of $C D 45^{\text {hi }}$ and $C D 45^{\text {med }}$ gating, elimination of $1 A 8^{+}$PMN, and selection for CD11 b cells that are GFPlo or GFPhi (B) Sequential confocal sections of GFPhi DC engulfing Dil-labeled RGC seven days post-ONC. Dil-labeled RGC, red; GFPhi DC, green; DAPI-stained nuclei, blue. (C) Detection and quantitation of Dil-labeled CD45 ${ }^{\text {med }} \mathrm{CD} 11 \mathrm{~b}^{+} \mathrm{GFP}{ }^{\text {hi }} \mathrm{DC}$ and GFPlo cells by flow cytometry. Ipsilateral retinas were labeled by injection of Dil into the superior colliculus. After seven days, mice were given an ONC; retinas were harvested six days later. 
The time course of Dil uptake into $\mathrm{CD}_{11} \mathrm{~b}^{+}$cells was determined next. Based on the progression of RGC apoptosis, estimated by counts of $\mathrm{TUNEL}^{+}$cells in the
RGC layer (Figure 5A), DiI-labeled retinas were harvested from 7 to 17 days post-ONC and analyzed by flow cytometry to detect DiI uptake by phagocytic $\mathrm{CD}_{11 \mathrm{~b}^{+}}$
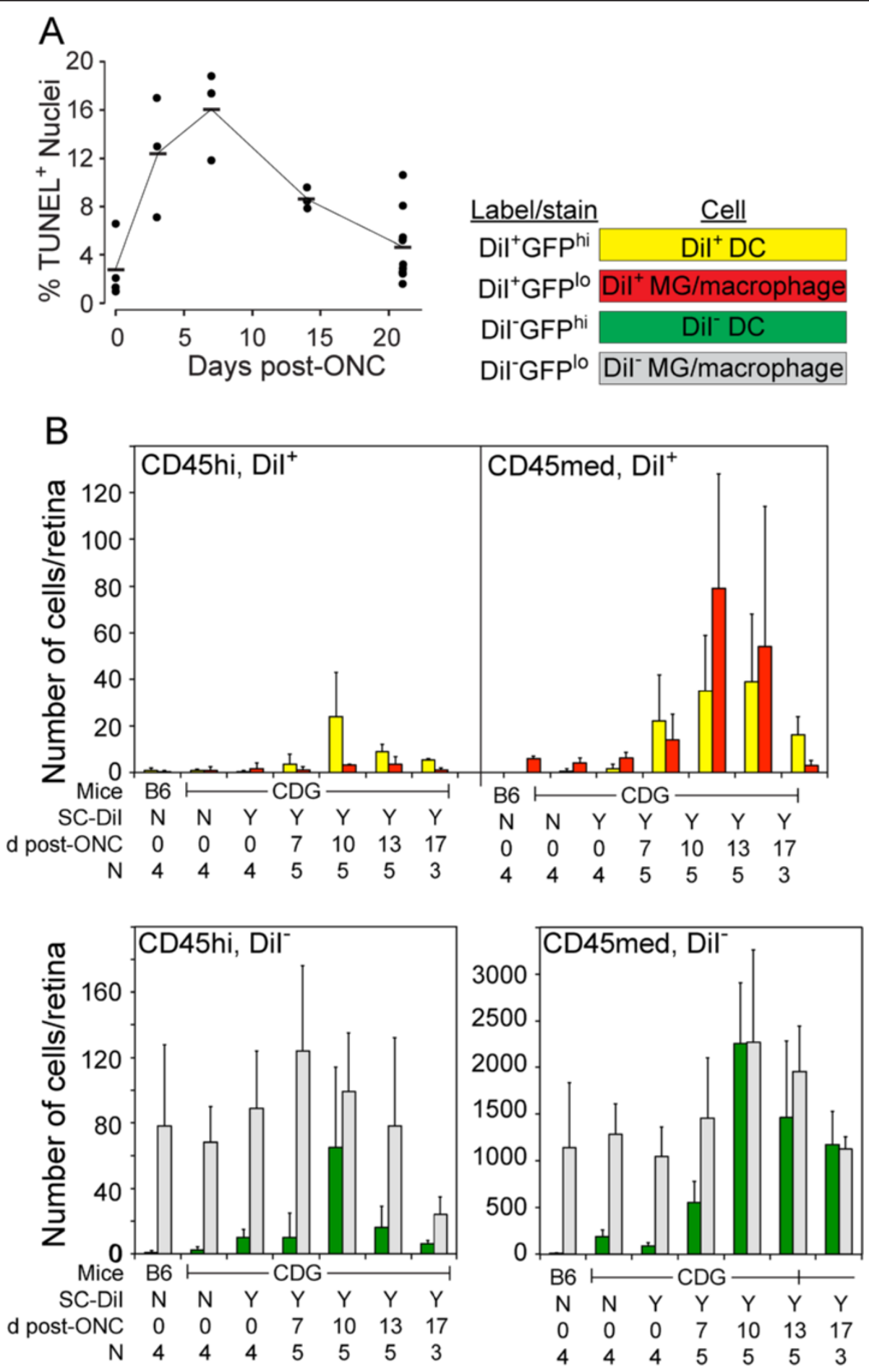

Figure 5 Phagocytosis of retinal ganglion cells (RGC) following an optic nerve injury (ONC). (A) Time course of RGC apoptosis following an ONC. (B) Analysis of Dil uptake in GFPhi DC and GFPlo MG/macrophages following an ONC. Retinas were labeled by injection of Dil into the superior colliculus. After 7 days the mice were given an ONC; retinas were harvested 7, 10, 13, and 17 days later. CD45 cells were examined by flow cytometry as shown in Figure 4. All cells in (B) are CD11 b+. 
cells in $\mathrm{CD} 45^{\mathrm{med}}$ and $\mathrm{CD} 45^{\text {hi }}$ populations (Figure $5 \mathrm{~B}$ ). The number of $\mathrm{DiI}^{+} \mathrm{CD} 11 \mathrm{~b}^{+}$cells peaked at ten days postONC in both CD $45^{\text {hi }}$ and CD $45^{\text {med }}$ populations. Although the total number of $\mathrm{CD}_{11 \mathrm{~b}^{+}}$cells in the $\mathrm{CD} 45^{\mathrm{hi}}$ population was much lower than the $\mathrm{CD} 45^{\text {med }}$ population, the frequency of $\mathrm{CD} 45^{\mathrm{hi}} \mathrm{DiI}^{+}$cells at day 10 post-ONC was much higher (14\%, 27 of 191 cells), than that found in the CD $45^{\text {med }}$ population $(2.5 \%, 115$ of 4,638 cells) (Figure $5 \mathrm{~B})$. Of the total $\mathrm{CD} 45^{\mathrm{hi}} \mathrm{DiI}{ }^{+} \mathrm{CD} 11 \mathrm{~b}^{+}$cells, $89 \%$ were $\mathrm{GFP}^{\mathrm{hi}}$, whereas only $35 \%$ of the $\mathrm{CD} 45^{\mathrm{med}} \mathrm{DiI}^{+}$cells were $\mathrm{GFP}^{\mathrm{hi}}$. These results showed that mononuclear cells were actively phagocytosing DiI-labeled RGC, and proportionately more of the $\mathrm{DiI}^{+}$cells were CD $45^{\text {hi }}$ DC. Since day 10 post-ONC was the peak of DiI uptake, day 10 was used for subsequent experiments.

\section{MyD88/TRIF and recruitment of CD11 $\mathrm{b}^{+}$myeloid cells to retina post-ONC}

Given the active participation of mononuclear cells in the clearing of RGC debris, we sought evidence for the contribution of toll-like receptors (TLR) to this response. A number of recent reports suggested roles for TLR in the responses of CNS tissue to injury and/or neurodegeneration [34,35]. The adaptor proteins MyD88 and TRIF link TLR ligation to NFKB activation. Their deletion has been reported to reduce neural inflammatory responses to infectious agents [36-39], and has been associated with an increase in neural deficits or diminished neurotoxicity [40]. Since the $\mathrm{GFP}^{+} \mathrm{DC}$ appeared in substantial numbers in the retina following injury, were closely associated with injured neurons, and phagocytosed RGC and axon debris, we asked if these activities correlated with TLR-mediated sensing of the local environment. Mko, Tko, and MTdko mice were backcrossed to the CDG background to examine the effects of eliminating these proteins on the influx of GFP ${ }^{\text {hi }} \mathrm{DC}$ and $\mathrm{GFP}^{\mathrm{lo}} \mathrm{MG}$ and macrophages in response to the ONC. Prior to injury, Tko and MTdko mice had reduced numbers of $\mathrm{CD} 45^{\text {med }} \mathrm{GFP}^{\text {hi }} \mathrm{DC}$ in the retina compared to control mice (Figure 6, Top). Deficiencies in either MyD88 or TRIF or both also led to a substantial reduction in the number of $\mathrm{GFP}^{\text {hi }} \mathrm{DC}$ that were recruited in response to an ONC (Figure 6, Bottom). The double knockout mice gave the greatest decline in retinal GFP ${ }^{\text {hi }}$ $\mathrm{DC}$ for both basal and post-ONC conditions, suggesting that the NFkB pathway regulated the response of mononuclear cells to an ONC. The flow cytometry conditions shown in Figures 4 and 6 were then analyzed for DiI to generate the data for Figures 7 and 8, which follow.

\section{MyD88/TRIF deficiency diminished uptake of Dil-labeled RGC debris by GFP ${ }^{\text {hi }}$ DC post-ONC}

The $C D 45^{\text {hi }}$ and $C D 45^{\text {med }}$ populations were examined for the effects of MyD88 and/or TRIF deficiency on

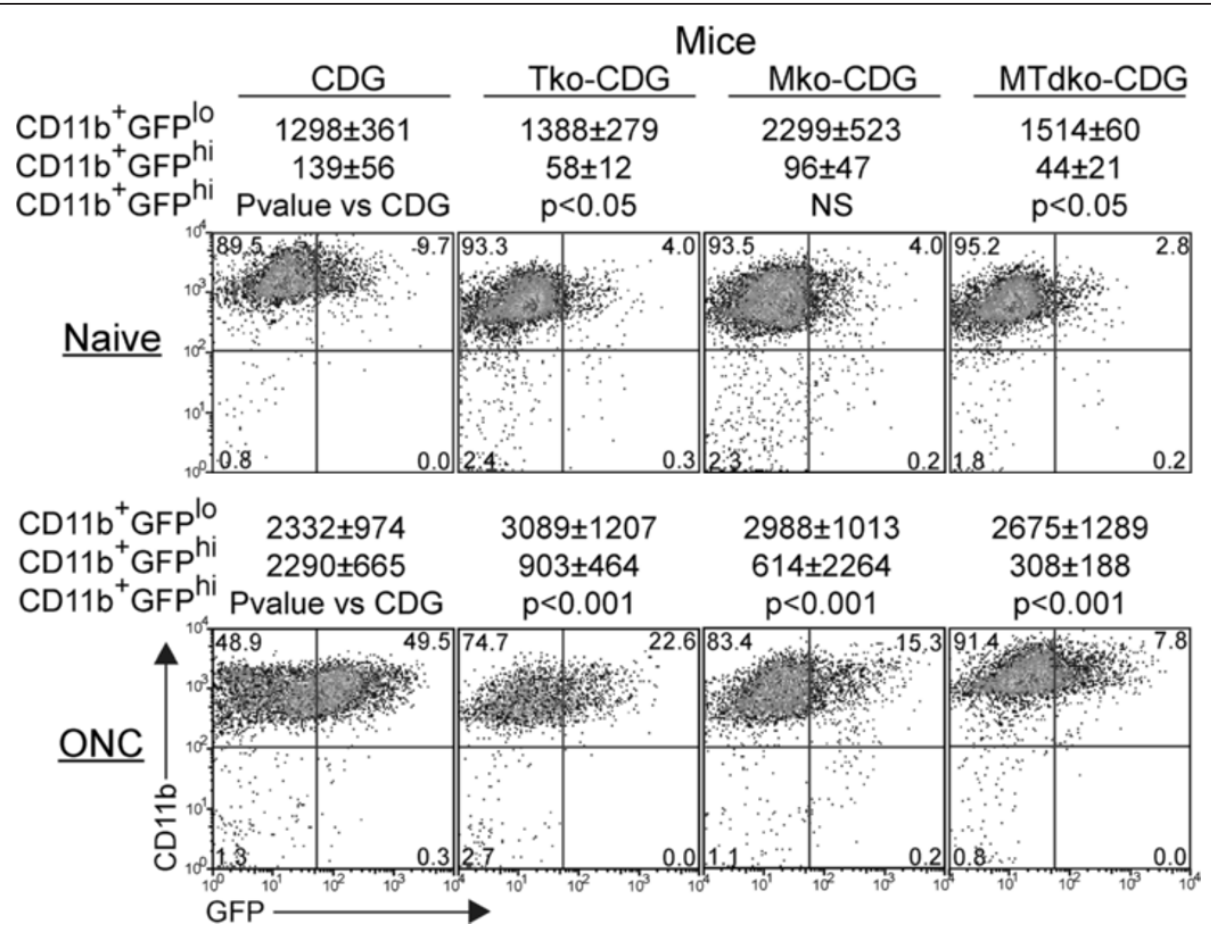

Figure 6 Recruitment of CD45 ${ }^{\text {med }}$ GFP hi cells to retina in Tko, Mko, or MTdko mice on the CDG background. Retinas were harvested ten days after an ONC. Numbers in the quadrants are percents, and are the averages of at least four samples. P-values for differences in the populations are shown. 


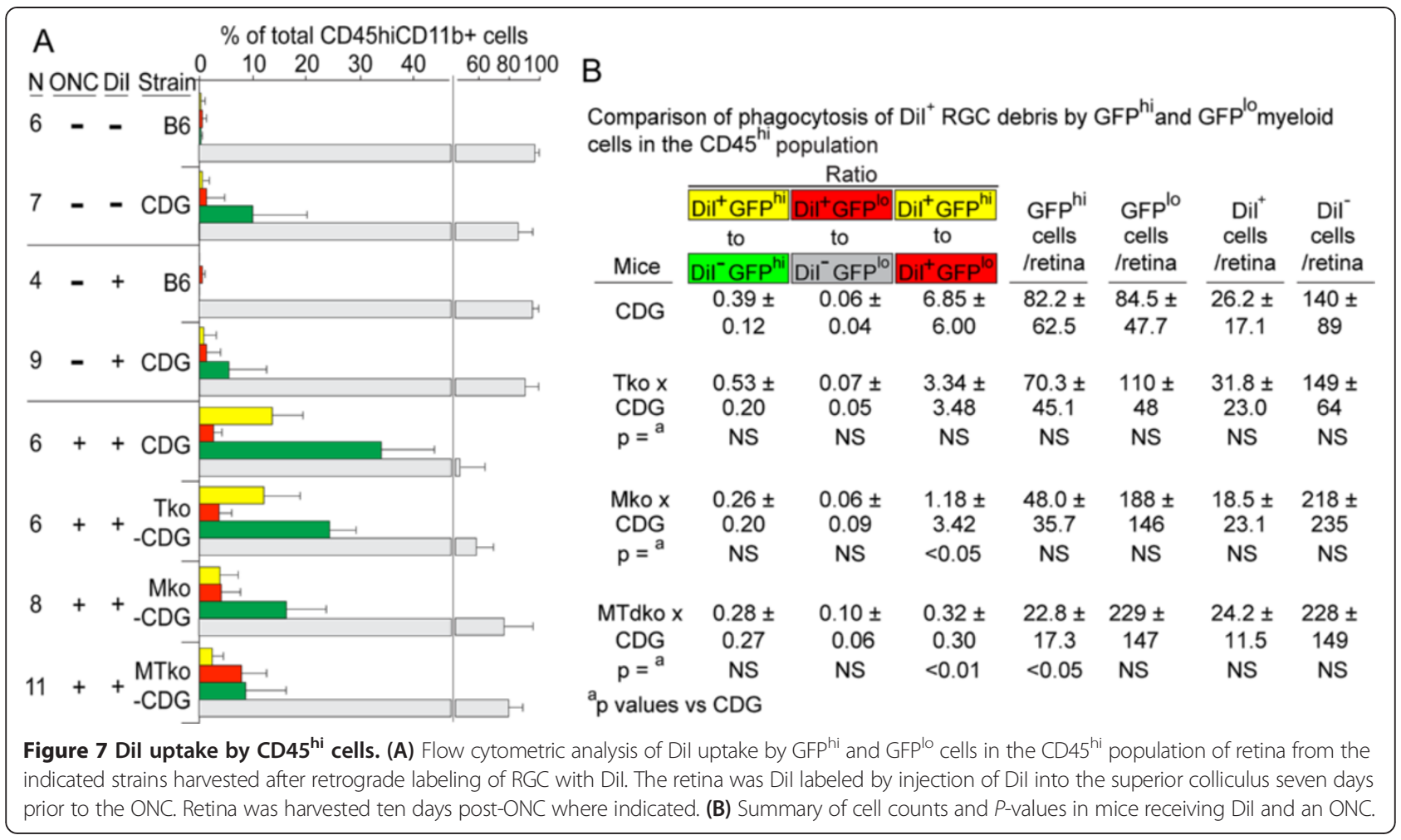

clearance of DiI-labeled RGC debris. The mononuclear cells in the CD $45^{\text {hi }}$ population became labeled with DiI after an ONC, regardless of the presence or absence of MyD88 or TRIF (Figure 7); the differences due to MyD88 and TRIF activity were found in the number of cells that were recruited by the injury. In control CDG mice, $39 \%$ of the GFP ${ }^{\text {hi }}$ DC were DiI labeled (yellow versus green bars), compared to $6 \%$ of $\mathrm{CD} 11 \mathrm{~b}^{+} \mathrm{GFP}^{\mathrm{lo}}$ cells that were found to be $\mathrm{DiI}^{+}$(red versus gray bars) (Figure $7 \mathrm{~B}$ ). Although the recruitment of GFP ${ }^{\text {hi }}$ DC into the CD $45^{\text {hi }}$

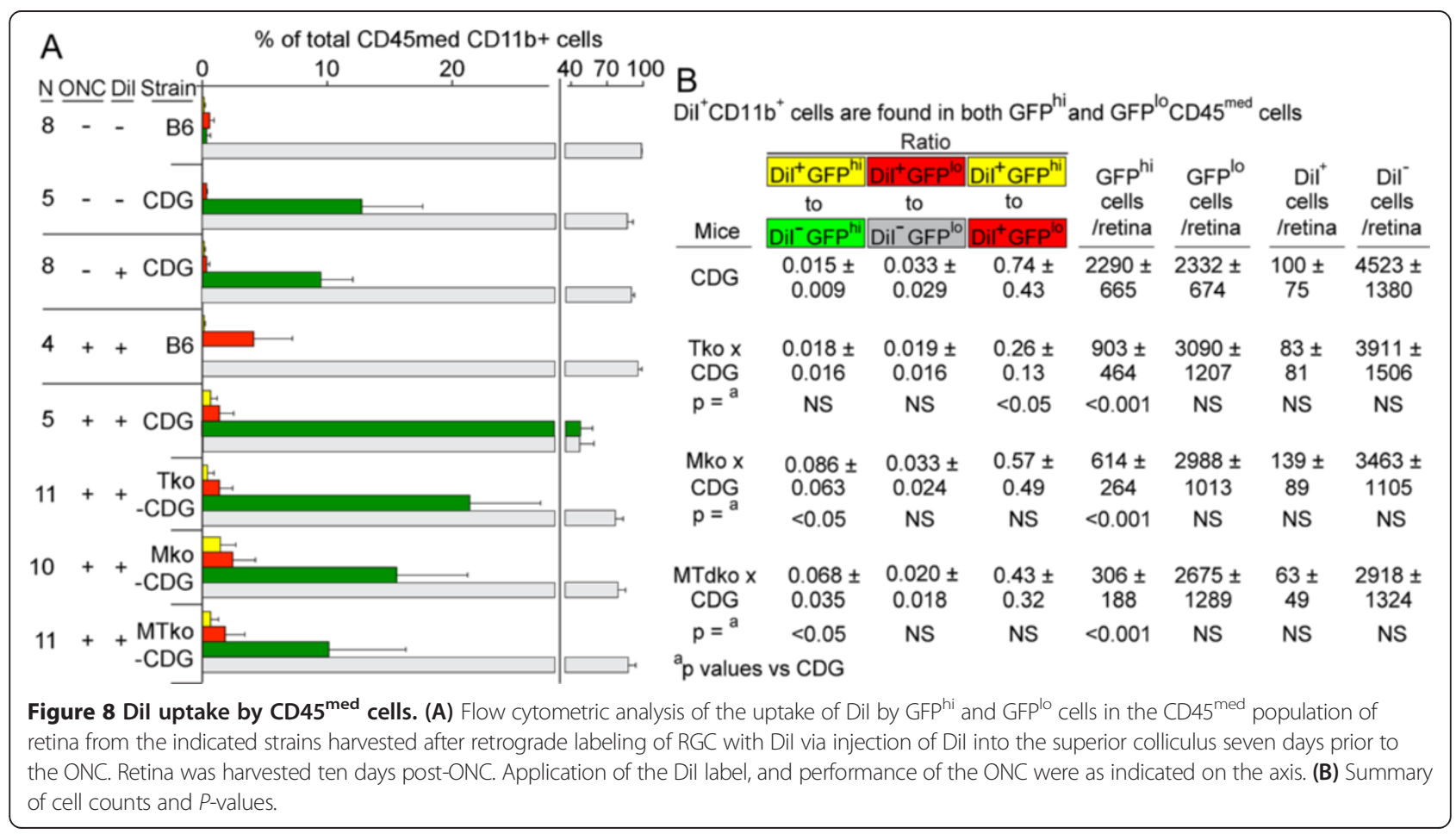


population declined in the MTdko mice, the fraction of $\mathrm{DiI}^{+} \mathrm{GFP}^{\text {hi }}$ cells relative to $\mathrm{GFP}^{+}$cells did not change significantly (Figure 7B). The fraction of $\mathrm{DiI}^{+} \mathrm{GFP}^{\mathrm{lo}}$ cells ranged from 6 to $10 \%$, and was not significantly different. Although the total of CD $455^{\text {hi }} \mathrm{GFP}^{\text {hi }}$ cells declined substantially (from 82 to 23), the total number of $\mathrm{DiI}^{+}$cells was not different (Figure 7B); the $\mathrm{GFP}^{\mathrm{lo}}$ cells appeared to compensate for the smaller number of GFP ${ }^{\text {hi }}$ DC in the uptake of DiI-labeled debris. Clearly, the DiI ${ }^{+} \mathrm{GFP}^{\mathrm{hi}} \mathrm{DC}$ and the $\mathrm{DiI}^{+} \mathrm{GFP}^{\mathrm{lo}}$ cells responded differently to the deficiencies in MyD88 and/or TRIF.

As shown above, $\mathrm{CD} 11 \mathrm{~b}^{+} \mathrm{DiI}^{+}$cells were also found in the $\mathrm{CD} 45^{\mathrm{med}}$ population, but their frequency was much lower than seen in the CD45 ${ }^{\text {hi }}$ populations (Figure 8A). The effect of MyD88/TRIF deficiency differed, relative to the results seen above for $\mathrm{CD} 45^{\text {hi }}$ cells. For example, the number of $\mathrm{DiI}^{+}$cells, relative to the total number of $\mathrm{CD}_{11 b^{+}}$cells, was constant in control versus MTdko mice (1:46 in CDG retina versus 1:47 in CDG x MTdko retina) (Figure $8 \mathrm{~B}$ ). Although the total number of cells in the $\mathrm{CD} 45^{\text {med }}$ population of CDG retina was approximately 27 -fold higher than in the $\mathrm{CD} 45^{\mathrm{hi}}$ population, the total number of $\mathrm{CD} 45^{\mathrm{med}} \mathrm{DiI}^{+}$cells was only 4 -fold higher. A similar comparison of these populations in MTdko retina showed an 11-fold difference in total cell number and a 2.5 -fold difference in $\mathrm{DiI}^{+}$cells.

The basis for maintaining the DiI uptake in the face of a substantial decrease in $\mathrm{GFP}^{\text {hi }} \mathrm{DC}$ is the significant shift in the distribution of $\mathrm{DiI}^{+}$cells. Their frequency in $\mathrm{GFP}^{\mathrm{hi}}$ cells from CDG $\mathrm{x}$ MTdko retina was higher than in GFP $^{\text {hi }}$ cells from CDG retina (0.015 in CDG retina versus 0.068 in CDG $x$ MTdko retina; $P<0.05)$. Conversely, the proportion of $\mathrm{DiI}^{+} \mathrm{GFP}^{\mathrm{lo}}$ cells was not different in the CDG versus CDG x MTdko retina (0.020 versus 0.033 , NS) (Figure 8B). Since the number of $\mathrm{GFP}^{\text {hi }}$ DC/retina substantially declined in the MTdko mice $(P<0.001)$, but the $\mathrm{DiI}^{+}$cells did not, showed that uptake of debris was not significantly compromised by MyD88 and/or TRIF deficiency. The effect of MyD88/TRIF deficiency was more closely associated with recruitment of $\mathrm{GFP}^{\mathrm{hi}}$ cells. The GFP $^{\text {hi }}$ DC clear debris with similar efficiency, even though their numbers declined.

\section{Depletion of GFP ${ }^{\text {hi }}$ cells from retina by systemic DTx reveals their replacement with GFPlo cells}

The results above revealed an altered response to injured RGC following an ONC in MyD88 and/or TRIF deficient mice. The GFP ${ }^{\text {hi }}$ DC population was most actively associated with injured RGC, and most affected by manipulations of MyD88 and TRIF. Since they are DTx sensitive, DTx treatment of the mice allowed studies of the participation of DC in RGC degeneration post-ONC, within the context of MyD88 and TRIF deficiencies. Several DTx treatment protocols were examined to confirm the DTx sensitivity of retinal DC, and devise DTx treatment protocols that would allow comparison of the $\mathrm{ONC}$ injury response in the presence or absence of retinal DC.

To explore differences between GFP $^{\text {hi }}$ DC versus GFP $\mathrm{P}^{\text {lo }}$ macrophages with respect to the close association with RGC axons in the NFL post-ONC, systemic injections of DTx were examined. The ip (intraperitoneal) route was chosen to facilitate in vivo imaging, since the optical properties of the cornea would be preserved, and to establish that DTx readily crossed the blood/retinal barrier. Serial fundus photographs showed that DTx treatment via ip injection effectively depleted GFP ${ }^{\text {hi }}$ DC recruited to the retina by an ONC (Figure 9A-C). Panel A showed an elevated number of $\mathrm{GFP}^{\text {hi }}$ DC at 12 days post-ONC. Panel $B$ showed noticeable depletion in the same retina one day after ip injection of $200 \mathrm{ng}$ DTx. Panel C revealed that two days post-DTx injection gave near-total depletion of GFP ${ }^{\text {hi }}$ cells. Six serial ip injections of $10 \mathrm{ng}$ DTx, or two ip injections of $100 \mathrm{ng}$, substantially depleted the GFP ${ }^{\mathrm{hi}}$ DC from uninjured versus crush-injured retinas, respectively, based on flow cytometry (Figure 9D). Importantly, both showed retention of $\mathrm{GFP}^{\mathrm{lo}} \mathrm{CD} 11 \mathrm{~b}^{+}$cells representing the MG/macrophages. Direct counts of GFP ${ }^{\text {hi }}$ cells in retinal flatmounts confirmed their depletion (Figure 9E). However, repeated systemic use of DTx for more than one week, even at low doses, was toxic. Accordingly, the short-term, high-dose protocol was used to explore the observation above that the MG replaced the DC interaction with RGC and axons, physically and functionally, in the MTdko mice.

Analysis of DTx depletion of GFP ${ }^{\text {hi }}$ DC by confocal microscopy of retinal wholemounts of ONC-injured CDG retinas given saline or 200 ng DTx ip showed depletion of the GFP ${ }^{\text {hi }}$ DC from the nerve fibers of the RGC (Figure 9F-K). In the saline-treated control mouse, multiple GFP ${ }^{\text {hi }}$ DC in close contact with the nerve fibers were found, and only a single $\mathrm{GFP}^{\mathrm{lo}}$ cell can be seen (Figure 9I). GFP ${ }^{\text {hi }}$ DC were prominent in the underlying IPL (Figure 9J and K). We previously showed that at 18 hours post-DTx, the retinal GFP ${ }^{\text {hi }}$ DC were depleted and the axons showed no association with $\mathrm{GFP}^{\mathrm{hi}}$ cells or with $\mathrm{GFP}^{\mathrm{lo}} \mathrm{CD} 11 \mathrm{~b}^{+} \mathrm{MG} /$ macrophages. Instead, the MG/ macrophages were seen intact, in the same field, below the RGC/NFL [21]. We show here that extending the time after DTx treatment to 48 hours before harvest revealed replacement of the $\mathrm{GFP}^{\text {hi }} \mathrm{DC}$ by the $\mathrm{GFP}^{\mathrm{lo}}$ macrophages/MG on the nerve fibers (Figure 9F), and continued presence of $\mathrm{GFP}^{\mathrm{lo}} \mathrm{MG} /$ macrophages in the underlying IPL (Figure 9G and $\mathrm{H}$ ).

\section{A two-niche model}

Taken together, the data supports a two-niche model for resident and recruited cells in retina (Figure 10). Niche 1 (N1) is occupied by MG/macrophages. In the resting 


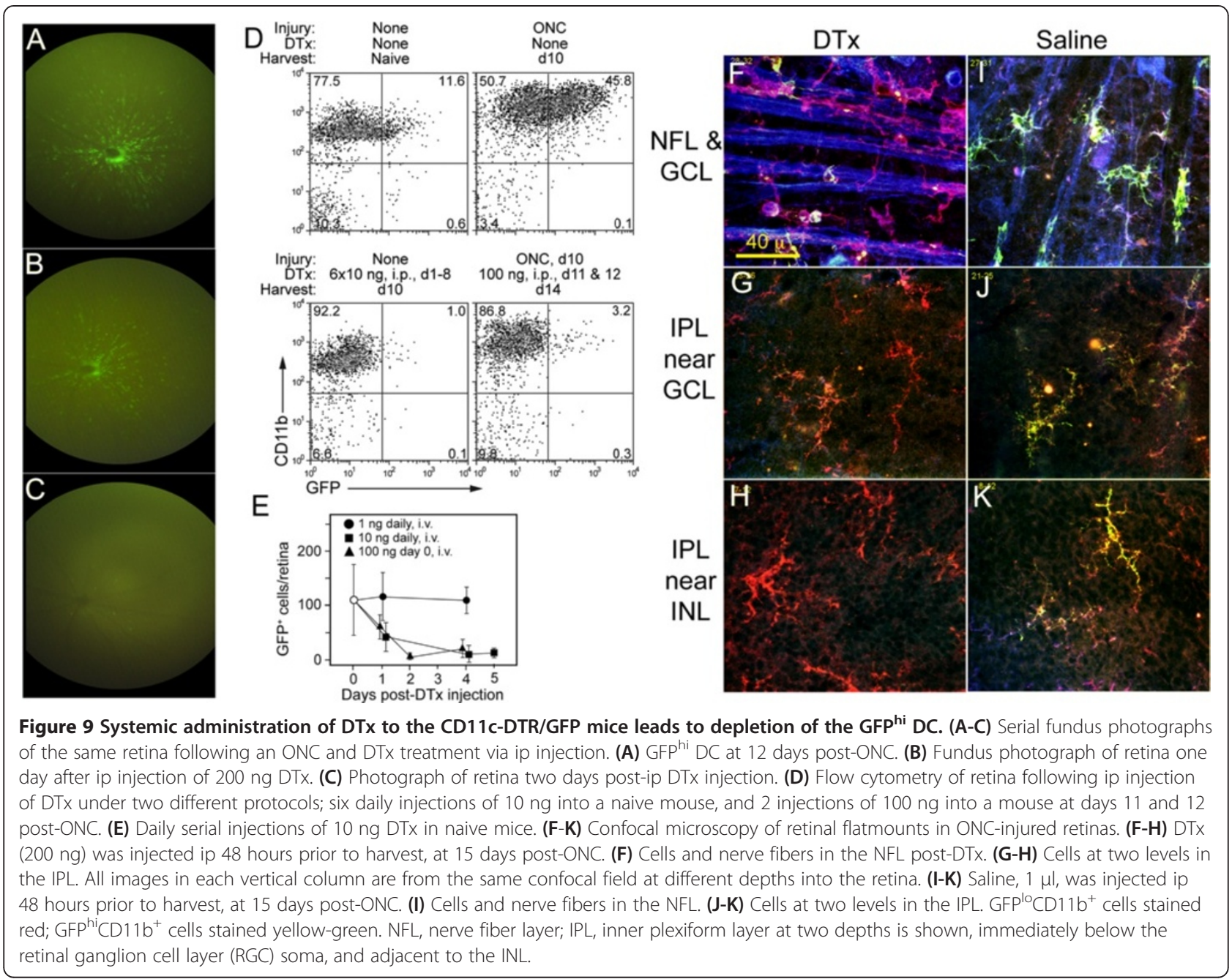

retina, this population far outweighs the $\mathrm{GFP}^{+} \mathrm{DC}$ in niche 2 (N2). Upon stimulation, the majority of cells occupy an expanding N2 population. Shrinkage of N2 occurs with resolution, although levels remain somewhat elevated over time. Evidence from the MTdko mice suggests a role for $\mathrm{NFK}_{\mathrm{B}}$ signaling in the migration of cells into the retina under both resting and stimulated conditions.

\section{Discussion}

We previously reported that DC identified as CD11b $\mathrm{GFP}^{\text {hi }}$ cells in CDG mice strongly responded to retinal injury, and that their numbers often equaled those of the MG, or other recruited GFP ${ }^{\text {lo }}$ macrophages [21]. DC are central components in innate and adaptive immunity, expressing a wide range of receptors that sample the environment for molecules indicative of cell health, infection or disease. Their extensive and close association with RGC and their axons after an ONC raised the possibility that they were active participants in the RGC injury response. TLR, and several other receptors, are important sensors linked to $\mathrm{NF} k \mathrm{~B}$ via the adaptor proteins MyD88 and TRIF [41]. Some studies have shown that neural inflammation was reduced, and neuron survival enhanced following injuries in MyD88- or TRIFdeficient mice [42-45], while others reported that MyD88 deficiency led to exacerbation of the injury response and less neuroprotection [46]. We explored the retinal DC response in mice deficient in one or both adaptor proteins.

Unlike MG, DC were transient participants in the injury response, first observed interacting with the NFL at three days post-injury, rising rapidly to peak at seven to thirteen days post-injury, and then declining in number. The subpopulation of retinal GFP ${ }^{\text {hi }}$ DC that expressed CD45 at a high level, resembling that of circulating myeloid DC progenitors, was most active in acquiring the DiI label contained in the RGC. GFP ${ }^{\text {hi }}$ cells engulfing DiI-labeled RGC soma post-ONC were readily identified by fluorescence microscopy. GFP ${ }^{\text {hi }}$ DC with CD45 expression at a lower level similar to MG also took up DiI post-injury, as did MG/macrophages that were CD $45^{\text {med }}$ and GFP ${ }^{\mathrm{lo}}$. 


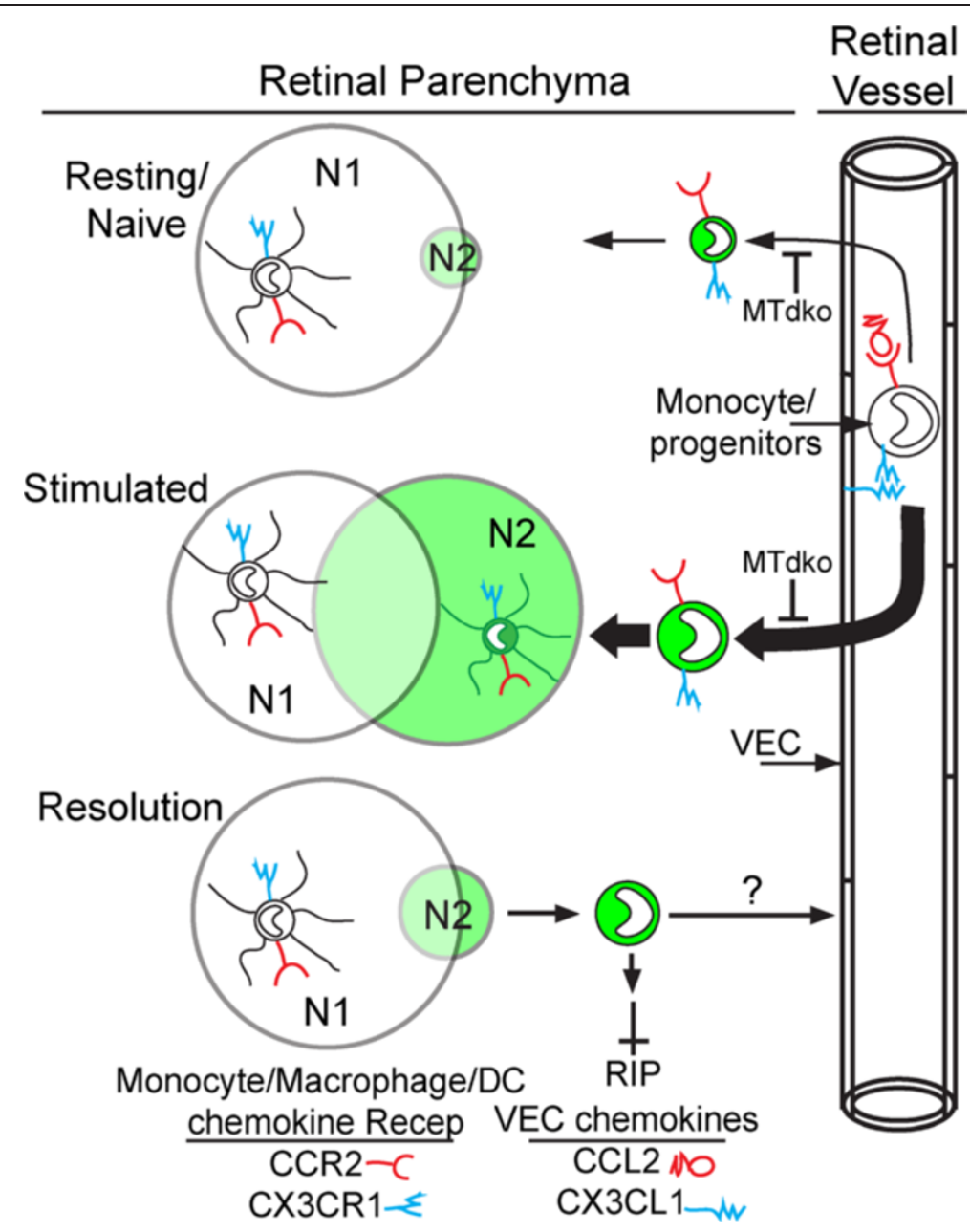

Figure 10 A two-niche model for resident and recruited cells in retina post-injury. The sizes of the niches, N1 (MG/macrophage niche) and N2 (GFPhi DC niche), as well as the arrows denoting pathways, were drawn to suggest relative sizes, and changes due to injury. VEC, vascular endothelial cells.

A key difference between GFP ${ }^{\text {hi }}$ DC and MG is that relatively few $\mathrm{GFP}^{\mathrm{hi}} \mathrm{DC}$ remain in the retina long-term, whereas MG are defined as long-term resident macrophages. Emigration of $\mathrm{GFP}^{\text {hi }} \mathrm{DC}$ from retina during injury resolution appears unlikely to occur by lymphatic drainage, but their numbers decline by an unknown mechanism. Their decline in numbers suggests that the numbers of $\mathrm{DiI}^{+} \mathrm{GFP}^{\mathrm{hi}} \mathrm{DC}$ may be underestimated due to turnover. A few thousand GFP ${ }^{\text {hi }}$ DC appear, have the opportunity to acquire $\mathrm{DiI}^{+}$debris, and disappear with their label over the course of two to three weeks, while the number of MG remains relatively constant.

$\mathrm{T}$ cell adaptive immune responses may contribute to neuroprotection. A number of neurodegenerative diseases/injuries are 'sterile', so that the antigens are limited to self-antigens. Nervous system self-antigen targets for immunopathogenic CNS autoimmune responses were reported to promote RGC survival post-ONC [47], perhaps by activated autoreactive $\mathrm{T}$ cells secreting neurotrophic factors promoting neuron survival [48]. Selfreactive Tregs were found to reduce RGC survival $[23,24]$. DC are the prototypical antigen presenting cells, and we showed elsewhere that retinal $\mathrm{GFP}^{+} \mathrm{DC}$ present antigen to antigen-specific T cells [29], and that retinal DC upregulate MHC class II expression following ONC [21]. These properties may further link the role of retinal DC to $\mathrm{T}$ cells and influence neuroprotection.

Although infiltrating monocytic cells were the major source of $\mathrm{TLR}^{+}$cells in traumatic brain injury [34], signaling pathways to $\mathrm{NF \kappa B}$ activation in retina are not straightforward, a result that has been observed by others $[49,50]$. In preliminary studies, we found that the canonical signaling pathway via RelA is not well-used in vivo by mononuclear cells in murine retina (data not shown). Further, since the entire mouse shares in adaptor protein deficiency in these knockout mice, some outcomes 
may negate each other. This may account for results showing neuroprotection [46] or a lack of effect $[51,52]$ in MyD88 and/or TRIF-deficient mice.

\section{A two-niche model for resident microglia and transient dendritic cells}

Several observations suggest the presence of two overlapping niches in retina, the resident MG niche (N1) maintained at a relatively stable number, and a transient niche (N2) created by injury or inflammation that becomes occupied by recruited mononuclear cells, including GFP ${ }^{\text {hi }}$ DC (Figure 10). The finding that sublethal irradiation protects from glaucoma in DBA/2 J mice by reducing monocyte entry in the irradiated retina/ON [53] is consistent with a two-niche model. Retinal DC appear to occupy N2, distinct from MG/macrophages in N1. Relative to the GFP ${ }^{\text {hi }}$ DC in CDG retina, their recruitment in MTdko retina is substantially reduced (note Figure 6), but the $\mathrm{GFP}^{\text {hi }}$ cells that were recruited exhibited a similar ability to take up DiI-labeled RGC following an ONC. While the number of GFP ${ }^{\text {hi }}$ cells peaked at seven to thirteen days post-ONC followed by a rapid decline, moderately increased numbers persisted for at least two months post-ONC [21]. No definitive marker has been found to distinguish MG from DC, nor have factors that sustain $\mathrm{N} 1$ or $\mathrm{N} 2$ been identified. If these cells occupied the same niche, one would expect that both MG and the $\mathrm{GFP}^{+}$cells would decline in proportion to their numbers, as the total number of cells returned to pre-injury levels. However, in the absence of catastrophic injury, N1 appears to continue to be occupied by MG, as allelic or other markers of recruited cells decline [54].

The chemokines and receptors that support recruitment of circulating precursors into multiple tissues, $\mathrm{C}-\mathrm{C}$ chemokine receptor-2/C-C chemokine ligand-2 (CCR2/ CCL2) and C-X3-C chemokine ligand-1; CX3CR1, CX3-C chemokine receptor-1 (CX3CL1/CX3CR1) [55], do not appear to be strong candidates for mediating the recruitment, function or maintenance of the cells in retinal N1 [56], but may have more effect on N2. The effect of CX3CR1-deficiency on experimental autoimmune uveoretinitis (EAU) pathogenesis in mice was found to be insignificant by one lab [57], but was associated with more severe EAU by another [58]. Further, no evidence for effects on retinal development or injury repair was associated with CX3CR1 deficiency [59]. Evidence for differences in migration or tracking was found in mice deficient in both CCL2 and CX3CR1, but degenerative changes in the retina were not found [60]. Experimental autoimmune encephalomyelitis (EAE) was found to be more severe in CX3CR1-deficient mice [61], but in models for ischemia-reperfusion injury in kidney [62], spinal cord injury [63], and atherosclerosis [64], disease was less severe in $\mathrm{CCR} 2^{-1-}$ or $\mathrm{CX} 3 \mathrm{CR} 1^{-1-}$ mice, and attributed to reduced myeloid cell recruitment. Knockout of either or both of these receptor/ligand pairs yields mice whose retinal myeloid cells bear some resemblance to the MTdko mice; that is the MG niche is largely intact, but recruitment is diminished. This is likely due to the role of NFkB in production of CX3CL1 on endothelial cells [65] stimulated by IL-1 and TNF [66]. Similarly, upregulation of CCR2 mediated by TLR2 and TLR4 ligation [67] would be diminished in MTdko mice, leading to reduced expression of accessory molecules and integrins associated with migration of cells into the retina [68-70]. Recent experiments with depletion protocols that may allow specific depletion of CNS MG may yield valuable information on the $\mathrm{N} 1$ niche [71], and strategies to manipulate N2.

\section{Conclusions}

Use of MyD88 and/or TRIF deficient mice on the CDG background provided insights into the retinal injury response. Mice with single or double deficiencies in these adaptor proteins had reduced responses, based on finding fewer $\mathrm{GFP}^{\mathrm{hi}} \mathrm{DC}$ in injured retinas post-ONC. Although fewer in number, GFP ${ }^{\text {hi }}$ DC retained their ability to acquire $\mathrm{DiI}^{+}$debris, suggesting that expression of these adaptor proteins, and their role in NFKB signaling, was not a factor in their ability to phagocytose dying RGC. Recruitment of GFP ${ }^{\text {hi }}$ DC, and their phagocytic activity, were distinct processes in which recruitment was diminished, but phagocytic activity was not. Instead, $\mathrm{GFP}^{\text {lo }}$ MG were more likely to become $\mathrm{DiI}^{+}$, suggesting that they filled the void left by the reduction in GFP hi DC in MyD88/TRIF-deficient mice.

\section{Additional file}

Additional file 1: Figure S1. Comparison of RGC counts/field obtained by manual and autocounting protocols. FG labeling combined with automated RGC counting was done to reduce observer bias. Field size $=0.190 \mathrm{~mm}^{2}$.

\section{Abbreviations}

AMD: age-related macular degeneration; ANOVA: analysis of variance; B6: C57BL/6J; CCL2: C-C chemokine ligand-2; CCR2: C-C chemokine receptor-2; CDG: CD11C-DTR/GFP; CX3CL1: C-X3-C chemokine ligand-1; CX3CR1: C-X3-C chemokine receptor-1; DAPI: 4',6-diamidino-2-phenylindole; DC: dendritic cell; Dil: di-alkyl-indocarbocyanine; DPBS: Dulbecco's phosphate-buffered saline; DTR: diphtheria toxin receptor; DTx: diphtheria toxin; EAE: experimental autoimmune encephalomyelitis; EAU: experimental autoimmune uveoretinitis; FG: Fluorogold; GCL: ganglion cell layer; GFP: green fluorescent protein; IL-1: interleukin-1; IPL: inner plexiform layer; MG: microglia; MyD88: myeloid differentiation primary response gene (88); Mko: MyD88 knockout; MTdko: MyD88/TRIF double knockout; NFL: nerve fiber layer; NFKB: nuclear factor kappa-light-chain-enhancer of activated B cells; ONC: optic nerve crush; PMN: polymorphonuclear granulocytes; RGC: retinal ganglion cell; TLR2: toll-like receptor 2; TLR4: toll-like receptor 4; TNF: tumor necrosis factor; TRIF: TIR-domaincontaining adapter-inducing interferon- $\beta$; TkO: TRIF knockout; TUNEL: terminal deoxynucleotidyl transferase-mediated dUTP nick-end labeling; wt: wild type. 


\section{Competing interests}

The authors declare that they have no competing interests.

\section{Authors' contributions}

$\mathrm{NH}$ developed and validated procedures for flow cytometry and performed all flow cytometry studies. MP performed all surgical procedures, fluorescence microscopy and prepared photos. KM developed and validated the RGC autocounting protocol. SM supervised all molecular biology procedures for use and analysis of the transgenic mice. UL developed and performed studies using local and systemic DTx to deplete dendritic cells. SH performed and analyzed the TUNEL analysis of RGC. DF performed data analysis and statistics, manuscript editing and major revisions. WL adapted and demonstrated surgical procedures using the stereotaxic manipulator for retrograde labeling of RGC. DG conceived of the study, oversaw design and drafted the manuscript. All authors contributed to editing. All authors read and approved the final manuscript.

\section{Acknowledgements}

Supported by R01-EY021003 (DSG); the Wallin Neuroscience Discovery Fund (DSG); T32-EY07133 (UL); T32-AG029796 (SH); P30-EY011374; the Minnesota Lions Clubs; and Research to Prevent Blindness, Inc. The authors thank Heidi Roehrich and Thien Sam for technical assistance. We also thank Dr. J Douglas Cameron for a helpful critique of the results.

All labwork on this manuscript was performed by the authors while they were present at the University of Minnesota.

\section{Author details}

${ }^{1}$ Department of Ophthalmology \& Visual Neurosciences, University of Minnesota, Lions Research Bldg. Rm 314, 2001 6th St SE, Minneapolis, MN 55455, USA. ${ }^{2}$ Department of Neurosurgery, University of Minnesota, Minneapolis, MN 55455, USA.

Received: 29 June 2014 Accepted: 29 July 2014

Published: 13 August 2014

\section{References}

1. Voleti VB, Hubschman JP: Age-related eye disease. Maturitas 2013, 75:29-33.

2. Payne AJ, Kaja S, Sabates NR, Koulen P: A case for neuroprotection in ophthalmology: developments in translational research. Mo Med 2013, 110:429-436.

3. Chou CF, Cotch MF, Vitale S, Zhang X, Klein R, Friedman DS, Klein BE, Saaddine JB: Age-related eye diseases and visual impairment among U.S. adults. Am J Prev Med 2013, 45:29-35.

4. Thumann G: Prospectives for gene therapy of retinal degenerations. Curr Genomics 2012, 13:350-362.

5. Czeh M, Gressens $P$, Kaindl AM: The yin and yang of microglia. Dev Neurosci 2011, 33:199-209.

6. Amor S, Puentes F, Baker D, van der Valk P: Inflammation in neurodegenerative diseases. Immunology 2010, 129:154-169.

7. Peferoen L, Kipp M, van der Valk P, van Noort JM, Amor S: Oligodendrocyte-microglia cross-talk in the central nervous system. Immunology 2014, 141:302-313.

8. Streit WJ, Mrak RE, Griffin WS: Microglia and neuroinflammation: a pathological perspective. J Neuroinflammation 2004, 1:14.

9. Takahashi K, Rochford CD, Neumann H: Clearance of apoptotic neurons without inflammation by microglial triggering receptor expressed on myeloid cells-2. J Exp Med 2005, 201:647-657.

10. Sanders $\mathrm{VM}$, Jones $\mathrm{KJ}$ : Role of immunity in recovery from a peripheral nerve injury. J Neuroimmune Pharmacol 2006, 1:11-19.

11. Van Eldik LJ, Thompson WL, Ralay Ranaivo H, Behanna HA, Martin Watterson D: Glia proinflammatory cytokine upregulation as a therapeutic target for neurodegenerative diseases: function-based and target-based discovery approaches. Int Rev Neurobiol 2007, 82:277-296.

12. Akiyama H, Barger S, Barnum S, Bradt B, Bauer J, Cole GM, Cooper NR, Eikelenboom P, Emmerling M, Fiebich BL, Finch CE, Frautschy S, Griffin WS, Hampel H, Hull M, Landreth G, Lue L, Mrak R, Mackenzie IR, McGeer PL, O'Banion MK, Pachter J, Pasinetti G, Plata-Salaman C, Rogers J, Rydel R, Shen Y, Streit W, Strohmeyer R, Tooyoma I, et al: Inflammation and Alzheimer's disease. Neurobiol Aging 2000, 21:383-421.
13. Stagi M, Dittrich PS, Frank N, Iliev Al, Schwille P, Neumann H: Breakdown of axonal synaptic vesicle precursor transport by microglial nitric oxide. J Neurosci 2005, 25:352-362.

14. Qiu J, Whalen MJ, Lowenstein P, Fiskum G, Fahy B, Darwish R, Aarabi B, Yuan J, Moskowitz MA: Upregulation of the Fas receptor death-inducing signaling complex after traumatic brain injury in mice and humans. J Neurosci 2002, 22:3504-3511.

15. Ju KR, Kim HS, Kim JH, Lee NY, Park CK: Retinal glial cell responses and Fas/FasL activation in rats with chronic ocular hypertension. Brain Res 2006, 1122:209-221.

16. Davalos D, Grutzendler J, Yang G, Kim JV, Zuo Y, Jung S, Littman DR, Dustin ML, Gan WB: ATP mediates rapid microglial response to local brain injury in vivo. Nat Neurosci 2005, 8:752-758.

17. Lee JE, Liang KJ, Fariss RN, Wong WT: Ex vivo dynamic imaging of retinal microglia using time-lapse confocal microscopy. Invest Ophthalmol Vis Sci 2008, 49:4169-4176.

18. Damani MR, Zhao L, Fontainhas AM, Amaral J, Fariss RN, Wong WT: Agerelated alterations in the dynamic behavior of microglia. Aging Cell 2011, 10:263-276.

19. Blanch RJ, Ahmed Z, Berry M, Scott RA, Logan A: Animal models of retinal injury. Invest Ophthalmol Vis Sci 2012, 53:2913-2920.

20. Berry M, Ahmed Z, Lorber B, Douglas M, Logan A: Regeneration of axons in the visual system. Restor Neurol Neurosci 2008, 26:147-174.

21. Lehmann U, Heuss ND, McPherson SW, Roehrich H, Gregerson DS: Dendritic cells are early responders to retinal injury. Neurobiol Dis 2010, 40:177-184.

22. Kipnis J, Yoles E, Schori H, Hauben E, Shaked I, Schwartz M: Neuronal survival after CNS insult is determined by a genetically encoded autoimmune response. J Neurosci 2001, 21:4564-4571.

23. Kipnis J, Mizrahi T, Hauben E, Shaked I, Shevach E, Schwartz M: Neuroprotective autoimmunity: naturally occurring CD4 + CD25+ regulatory $T$ cells suppress the ability to withstand injury to the central nervous system. Proc Natl Acad Sci U S A 2002, 99:15620-15625.

24. Kipnis J, Avidan H, Caspi RR, Schwartz M: Dual effect of CD4 + CD25+ regulatory $T$ cells in neurodegeneration: a dialogue with microglia. Proc Natl Acad Sci U S A 2004, 101(Suppl 2):14663-14669.

25. Wax MB, Tezel G, Yang J, Peng G, Patil RV, Agarwal N, Sappington RM, Calkins DJ: Induced autoimmunity to heat shock proteins elicits glaucomatous loss of retinal ganglion cell neurons via activated T-cellderived fas-ligand. J Neurosci 2008, 28:12085-12096.

26. Jung S, Unutmaz D, Wong P, Sano G, De los Santos K, Sparwasser T, Wu S, Vuthoori S, Ko K, Zavala F, Pamer EG, Littman DR, Lang RA: In vivo depletion of $\mathrm{CD} 11 \mathrm{c}(+)$ dendritic cells abrogates priming of $\mathrm{CD} 8(+) \mathrm{T}$ cells by exogenous cell-associated antigens. Immunity 2002, 17:211-220.

27. Li Y, Schlamp CL, Nickells RW: Experimental induction of retinal ganglion cell death in adult mice. Invest Ophthalmol Vis Sci 1999, 40:1004-1008.

28. McPherson SW, Heuss ND, Gregerson DS: Local 'on-demand' generation and function of antigen-specific foxp3+ regulatory T cells. J Immunol 2013, 190:4971-4981.

29. Heuss ND, Lehmann U, Norbury CC, MCPherson SW, Gregerson DS: Local activation of dendritic cells alters the pathogenesis of autoimmune disease in the retina. J Immunol 2012, 188:1191-1200.

30. Jeon CJ, Strettoi E, Masland RH: The major cell populations of the mouse retina. J Neurosci 1998, 18:8936-8946.

31. Cone FE, Gelman SE, Son JL, Pease ME, Quigley HA: Differential susceptibility to experimental glaucoma among 3 mouse strains using bead and viscoelastic injection. Exp Eye Res 2010, 91:415-424.

32. Pang JJ, Wu SM: Morphology and immunoreactivity of retrogradely double-labeled ganglion cells in the mouse retina. Invest Ophthalmol Vis Sci 2011, 52:4886-4896.

33. Schlamp CL, Montgomery AD, Mac Nair CE, Schuart C, Willmer DJ, Nickells RW: Evaluation of the percentage of ganglion cells in the ganglion cell layer of the rodent retina. Mol Vis 2013, 19:1387-1396.

34. Zhang Z, Zhang ZY, Wu Y, Schluesener HJ: Immunolocalization of Toll-like receptors 2 and 4 as well as their endogenous ligand, heat shock protein 70, in rat traumatic brain injury. Neuroimmunomodulation 2012, 19:10-19.

35. Babcock AA, Toft-Hansen H, Owens T: Signaling through MyD88 regulates leukocyte recruitment after brain injury. J Immunol 2008, 181:6481-6490.

36. Esen N, Kielian T: Central role for MyD88 in the responses of microglia to pathogen-associated molecular patterns. J Immunol 2006, 176:6802-6811.

37. Miranda-Hernandez S, Gerlach N, Fletcher JM, Biros E, Mack M, Korner H, Baxter AG: Role for MyD88, TLR2 and TLR9 but not TLR1, TLR4 or TLR6 in 
experimental autoimmune encephalomyelitis. J Immuno/ 2011, 187:791-804.

38. Torres M, Guiton R, Lacroix-Lamande S, Ryffel B, Leman S, Dimier-Poisson I: MyD88 is crucial for the development of a protective CNS immune response to Toxoplasma gondii infection. J Neuroinflammation 2013, 10:19.

39. Kumar H, Kawai T, Akira S: Pathogen recognition by the innate immune system. Int Rev Immunol 2011, 30:16-34.

40. Pimentel-Coelho PM, Michaud JP, Rivest S: Evidence for a gender-specific protective role of innate immune receptors in a model of perinatal brain injury. J Neurosci 2013, 33:11556-11572.

41. Barton GM, Medzhitov R: Linking Toll-like receptors to IFN-alpha/beta expression. Nat Immunol 2003, 4:432-433.

42. Lin S, Liang Y, Zhang J, Bian C, Zhou H, Guo Q, Xiong Y, Li S, Su B: Microglial TIR-domain-containing adapter-inducing interferon-beta (TRIF) deficiency promotes retinal ganglion cell survival and axon regeneration via nuclear factor-kappaB. J Neuroinflammation 2012, 9:39.

43. Hanafy KA: The role of microglia and the TLR4 pathway in neuronal apoptosis and vasospasm after subarachnoid hemorrhage. J Neuroinflammation 2013, 10:83.

44. Lim JE, Kou J, Song M, Pattanayak A, Jin J, Lalonde R, Fukuchi K: MyD88 deficiency ameliorates beta-amyloidosis in an animal model of Alzheimer's disease. Am J Pathol 2011, 179:1095-1103.

45. Michaud JP, Richard KL, Rivest S: MyD88-adaptor protein acts as a preventive mechanism for memory deficits in a mouse model of Alzheimer's disease. Mol Neurodegeneration 2011, 6:5.

46. Downes CE, Wong CH, Henley KJ, Guio-Aguilar PL, Zhang M, Ates R, Mansell A, Kile BT, Crack PJ: MyD88 is a critical regulator of hematopoietic cellmediated neuroprotection seen after stroke. PLoS One 2013, 8:e57948.

47. Mizrahi T, Hauben E, Schwartz M: The tissue-specific self-pathogen is the protective self-antigen: the case of uveitis. J Immunol 2002, 169:5971-5977.

48. Moalem G, Gdalyahu A, Shani Y, Otten U, Lazarovici P, Cohen IR, Schwartz M: Production of neurotrophins by activated T cells: implications for neuroprotective autoimmunity. J Autoimmun 2000, 15:331-345.

49. Mao X, Moerman AM, Barger SW: Neuronal kappa B-binding factors consist of Sp1-related proteins. Functional implications for autoregulation of N-methylD-aspartate receptor-1 expression. J Biol Chem 2002, 277:44911-44919.

50. Mao XR, Moerman-Herzog AM, Chen Y, Barger SW: Unique aspects of transcriptional regulation in neurons - nuances in NFkappaB and Sp1related factors. J Neuroinflammation 2009, 6:16.

51. Famakin BM, Mou Y, Ruetzler CA, Bembry J, Maric D, Hallenbeck JM: Disruption of downstream MyD88 or TRIF Toll-like receptor signaling does not protect against cerebral ischemia. Brain Res 2011, 1388:148-156.

52. Drouin-Ouellet J, Gibrat C, Bousquet M, Calon F, Kriz J, Cicchetti F: The role of the MYD88-dependent pathway in MPTP-induced brain dopaminergic degeneration. J Neuroinflammation 2011, 8:137.

53. Howell GR, Soto I, Zhu X, Ryan M, Macalinao DG, Sousa GL, Caddle LB, MacNicoll KH, Barbay JM, Porciatti V, Anderson MG, Smith RS, Clark AF, Libby RT, John SW: Radiation treatment inhibits monocyte entry into the optic nerve head and prevents neuronal damage in a mouse model of glaucoma. J Clin Invest 2012, 122:1246-1261.

54. Kaneko H, Nishiguchi KM, Nakamura M, Kachi S, Terasaki H: Characteristics of bone marrow-derived microglia in the normal and injured retina. Invest Ophthalmol Vis Sci 2008, 49:4162-4168.

55. Niess JH, Brand S, Gu X, Landsman L, Jung S, McCormick BA, Vyas JM, Boes M, Ploegh HL, Fox JG, Littman DR, Reinecker HC: CX3CR1-mediated dendritic cell access to the intestinal lumen and bacterial clearance. Science 2005, 307:254-258.

56. Kezic J, Xu H, Chinnery HR, Murphy CC, McMenamin PG: Retinal microglia and uveal tract dendritic cells and macrophages are not CX3CR1 dependent in their recruitment and distribution in the young mouse eye. Invest Ophthalmol Vis Sci 2008, 49:1599-1608.

57. Kezic J, McMenamin PG: The monocyte chemokine receptor CX3CR1 does not play a significant role in the pathogenesis of experimental autoimmune uveoretinitis. Invest Ophthalmol Vis Sci 2010, 51:5121-5127.

58. Dagkalis A, Wallace C, Hing B, Liversidge J, Crane IJ: CX3CR1-deficiency is associated with increased severity of disease in experimental autoimmune uveitis. Immunology 2009, 128:25-33.

59. Zhao L, Ma W, Fariss RN, Wong WT: Retinal vascular repair and neovascularization are not dependent on CX3CR1 signaling in a model of ischemic retinopathy. Exp Eye Res 2009, 88:1004-1013.
60. Luhmann UF, Carvalho LS, Robbie SJ, Cowing JA, Duran Y, Munro PM, Bainbridge JW, Ali RR: $\mathrm{Cl} 2, \mathrm{C} \times 3 \mathrm{cr} 1$ and $\mathrm{Ccl} 2 / \mathrm{C} \times 3 \mathrm{cr} 1$ chemokine deficiencies are not sufficient to cause age-related retinal degeneration. Exp Eye Res 2013, 107:80-87.

61. Garcia JA, Pino PA, Mizutani M, Cardona SM, Charo IF, Ransohoff RM, Forsthuber TG, Cardona AE: Regulation of adaptive immunity by the fractalkine receptor during autoimmune inflammation. J Immunol 2013, 191:1063-1072.

62. Li L, Huang L, Sung SS, Vergis AL, Rosin DL, Rose CE Jr, Lobo PI, Okusa MD: The chemokine receptors CCR2 and CX3CR1 mediate monocyte/ macrophage trafficking in kidney ischemia-reperfusion injury. Kidney Int 2008, 74:1526-1537.

63. Donnelly DJ, Longbrake EE, Shawler TM, Kigerl KA, Lai W, Tovar CA, Ransohoff RM, Popovich PG: Deficient CX3CR1 signaling promotes recovery after mouse spinal cord injury by limiting the recruitment and activation of Ly6Clo/iNOS + macrophages. J Neurosci 2011, 31:9910-9922.

64. Liu P, Yu YR, Spencer JA, Johnson AE, Vallanat CT, Fong AM, Patterson C, Patel DD: CX3CR1 deficiency impairs dendritic cell accumulation in arterial intima and reduces atherosclerotic burden. Arterioscler Thromb Vasc Biol 2008, 28:243-250.

65. Garcia GE, Xia Y, Chen S, Wang Y, Ye RD, Harrison JK, Bacon KB, Zerwes HG, Feng L: NF-kappaB-dependent fractalkine induction in rat aortic endothelial cells stimulated by IL-1beta, TNF-alpha, and LPS. J Leukoc Biol 2000, 67:577-584.

66. Popovic M, Laumonnier $Y$, Burysek L, Syrovets T, Simmet T: Thrombininduced expression of endothelial CX3CL1 potentiates monocyte CCL2 production and transendothelial migration. J Leukoc Biol 2008, 84:215-223.

67. Souto FO, Alves-Filho JC, Turato WM, Auxiliadora-Martins M, Basile-Filho A, Cunha FQ: Essential role of CCR2 in neutrophil tissue infiltration and multiple organ dysfunction in sepsis. Am J Respir Crit Care Med 2011, 183:234-242

68. Jimenez F, Quinones MP, Martinez HG, Estrada CA, Clark K, Garavito E, Ibarra J, Melby PC, Ahuja SS: CCR2 plays a critical role in dendritic cell maturation: possible role of CCL2 and NF-kappa B. J Immunol 2010, 184:5571-5581.

69. Ley K, Laudanna C, Cybulsky MI, Nourshargh S: Getting to the site of inflammation: the leukocyte adhesion cascade updated. Nat Rev Immunol 2007, 7:678-689

70. Pober JS, Sessa WC: Evolving functions of endothelial cells in inflammation. Nat Rev Immunol 2007, 7:803-815.

71. Parkhurst CN, Yang G, Ninan I, Savas JN, Yates JR 3rd, Lafaille JJ, Hempstead BL, Littman DR, Gan WB: Microglia promote learning-dependent synapse formation through brain-derived neurotrophic factor. Cell 2013, 155:1596-1609.

doi:10.1186/s12974-014-0143-

Cite this article as: Heuss et al:: Retinal dendritic cell recruitment, but not function, was inhibited in MyD88 and TRIF deficient mice. Journal of Neuroinflammation 2014 11:143.

\section{Submit your next manuscript to BioMed Central and take full advantage of:}

- Convenient online submission

- Thorough peer review

- No space constraints or color figure charges

- Immediate publication on acceptance

- Inclusion in PubMed, CAS, Scopus and Google Scholar

- Research which is freely available for redistribution 